Intersections

Canadian Journal of Music

Revue canadienne de musique
Intersections CANADAN IOURAA OO NUSTC

\title{
William Todd Schultz. 2013. Torment Saint: The Life of Elliott Smith. New York: Bloomsbury. 368 pp. ISBN 978-1-60819-973-0
}

\section{Matthew Ryan Smith}

Volume 34, numéro 1-2, 2014

URI : https://id.erudit.org/iderudit/1030883ar

DOI : https://doi.org/10.7202/1030883ar

Aller au sommaire du numéro

\section{Éditeur(s)}

Canadian University Music Society / Société de musique des universités canadiennes

ISSN

1911-0146 (imprimé)

1918-512X (numérique)

Découvrir la revue

Citer ce compte rendu

Smith, M. R. (2014). Compte rendu de [William Todd Schultz. 2013. Torment

Saint: The Life of Elliott Smith. New York: Bloomsbury. 368 pp. ISBN

978-1-60819-973-0]. Intersections, 34(1-2), 221-224.

https://doi.org/10.7202/1030883ar

Copyright @ Canadian University Music Society / Société de musique des universités canadiennes, 2015
Ce document est protégé par la loi sur le droit d'auteur. L'utilisation des services d'Érudit (y compris la reproduction) est assujettie à sa politique d'utilisation que vous pouvez consulter en ligne.

https://apropos.erudit.org/fr/usagers/politique-dutilisation/ 
Dorith Cooper, 114-23, CanMus Documents 2, Institute for Canadian Music, University of Toronto.

Diamond, Beverley. 1994. "Narratives of Canadian Music History." In Canadian Music: Issues of Hegemony and Identity, ed. Beverley Diamond and Robert Witmer, 139-71. Toronto: Canadian Scholars' Press.

Gordon E. SMITH

William Todd Schultz. 2013. Torment Saint: The Life of Elliott Smith. New York: Bloomsbury. 368 pp. ISBN 978-1-60819-973-0.

Elliott Smith entered mainstream consciousness during a surrealistic performance at the 1998 Academy Awards ceremony. Unintentionally evoking the absurdist strategies of early Dadaists such as Hugo Ball, the greasy-haired Smith took the stage in a white Prada suit opposite Jack Nicolson; in other words, a sore thumb amidst rows of Hollywood elite. His song "Miss Misery," which appeared in Gus Van Sant's 1997 film Good Will Hunting, had been nominated in the Best Original Song category. Although he eventually lost to Celine Dion's "My Heart Will Go On," Smith was hardly disappointed. Here was a master craftsman of lyricism and melody, arguably one of the greatest of the 1990s, moving towards wider audience and industry recognition.

William Todd Schultz's Torment Saint: The Life of Elliott Smith attempts to separate what he calls "The Smith Myth" from reality by approaching the musician's life through rigorous biographical study. Schultz is one of the foremost thinkers in "psychobiography" - a developing field of research that integrates biographical scholarship with psychological theory-having published the Handbook of Psychobiography (Oxford) in 2005. That being said, although this book does not explicitly apply psycho-biographical theory to Smith's life and music, it is written and reads as biography.

The introductory chapter and much of chapter 1 reconcile the lure of conflating Smith with the "tragic hero" archetype that he and many of his contemporaries such as Kurt Cobain and Daniel Johnston fall into. The latter is regarded as an "outsider" singer, songwriter, and visual artist, who was memorialized in the 2005 documentary The Devil and Daniel Johnston. According to Schultz, the hero is more or less "a blameless victim of wrongdoing. The hero stays pure. The hero is martyred" (8). Recognizing that romanticization shuts down meaning and the dynamic complexity of the musician's personal history, Schultz, much to his credit, inevitably finds Smith's music as a fundamental producer of meaning, rather than fleshing out meaning from biographical details alone.

A central problem that Schultz encounters with Smith is his plurality; for Schultz, "There are too many Elliott Smiths to count" (1). An avid reader of Kafka, Stendhal, and Freud, Smith wrote his undergraduate thesis at Hampshire College on post-structural feminist theory in law proceedings, citing Derridean "misreadings" and fluidity of interpretation (103). Applying such critical theory might have allowed Schultz to speculate on the sources of 
Smith's identity politics in greater detail, though its omission it is likely a result of the book's target audience being a largely non-academic readership.

Schultz ruminates on Smith's juvenilia in chapters 2 and 3 to chart his formative development, specifically the abandonment of Smith by his biological father, his mother's remarriage, and allegations of verbal, physical, and sexual abuse from her new husband. What emerges is a prolific young songwriter who channelled personal trauma for subject matter, but also a musical virtuoso who played Rachmaninoff with relative ease. This, combined with a staunch political opposition to Reaganism, is why Smith should be considered a classicist with punk rock verve. Schultz scrutinizes Smith's compositional virtues, noting that he "was fascinated by leading tones and passing chords, movements from verse to chorus and back to verse," where the subtleties in the song contribute to its overall "idiosyncratic signature" (53). Smith's committal to a $3 / 4$ waltz time signature in songs such as "Waltz \#2" almost certainly is a direct correlation. Schultz also exposes perhaps the most revealing condition of Smith's songwriting process in that he considered words not as language but as "shapes" (53), which essentially reveals Smith's understanding of cognitive psychology and semiotics.

Chapters 4 and 5 document Smith's nomadic movement from Texas to Seattle, and Portland, where he eventually settled to co-establish the band Heatmiser. Schultz ponders Smith's slow slide into depression during his time in Portland. He also took an intellectual interest in hell, which drove him further into depression, where alcohol became a crutch. "When he went dark," says Schultz, "he went darker than anyone else, to places where he seemed unreachable" (133). Using the psychobiography model, Schultz draws several conclusions of Smith's musical output during this period by drawing comparisons between his mental illness and lyrical expression. The connections are fascinating, considering that Smith's lyrics are often illuminating autobiographical utterances. What is commendable, though, is Schultz's mindful treatment of his subject as such, which is likely due to his critical background in psychology. The subject of lyrics is taken up further in relation to poetical devices, precisely of the Dylanesque variety-"a sort of poetry all its own" (190). It is a telling observation, namely because, like Bob Dylan, Smith reconstituted lyrical engagements by bridging poetical devices with traditional music composition.

Chapters 6 and 7 outline the critical groundswell overwhelming Smith's mid-nineties releases: the self-titled album Elliott Smith (1995), Either/Or (1997), and $X O$ (1998). Schultz explains that this time was among Smith's most prolific, writing and reworking numerous songs at once. However, along with this intense creative output came an increasing susceptibility to depression and selfmedication. Schultz describes how Smith's creative energy was often derived from painful mental states, and as the music improved, so too did the severity of the depression. Smith's alleged suicide attempt while running off a cliff in 1997 is the result of such emotional discord and a growing dependency on alcohol. Schultz uses the term fall to describe what is perhaps an accident; nevertheless it also stands as a metaphor, because the event is a clear turning point in Smith's life, leading directly to an intervention by friends and family that same 
year. After a brief stint in rehab, Smith sank into further depressive isolation. Schultz's lengthy profile of post-intervention Smith is rather insightful in the way that he draws connections between Smith's depression and Kierkegaard's analysis of depression. "There was depression," he writes, "Kierkegaard's 'faithful mistress,' which ... Elliott was in love with. He had a hard time imagining life without it, and he'd come to connect it to his creativity" (234). It is worth nothing that a certain solemnity pervades Schultz's finely written narrative, as if Smith's emotional circumstance pervades its pages.

In 2000 Smith was recording at Abbey Road studios for what became his magnum opus, Figure 8 (2000). Figure 8 was closely modelled after the album The Marble Index (1968) created by Nico, the German singer-songwriter and former member of the Velvet Underground, That same year Smith became addicted to heroin, then crack cocaine, and eventually a toxic soup of pharmaceutical drugs. Schultz notes, "Heroin has always been a lure, a sort of waving siren, a last-ditch option, and whoever made it available, Elliott took it" (277). For Schultz, the year 2000 represents another key shift in Smith's biography. He outlines Smith's abrupt cold kick of drugs in August 2003 and investigates the musical and psychological consequences of the revelation that Smith may have been sexually abused as a child. Schultz is correct in asserting that the years of tortuous suffering inflicted on his body through drugs and alcohol most likely left Smith with traces of paranoia, anxiety, painful memories, and depression, which exacerbated his personal issues further. It was here that, after a brief argument with his girlfriend Jennifer Chiba, Smith repeatedly stabbed himself in the chest and died. Months earlier, he had recorded what would be his last album, From a Basement on the Hill. Rightly so, "it was Elliott's Finnegan's Wake" (309). Though he does not fully explain the connection, presumably Schultz draws parallels between James Joyce's famously inscrutable literary experiment and Smith's own attempt at a concept album in From a Basement on the Hill.

Some of the most meaningful contributions of Torment Saint are its realworld consequences. Because the coroner who had examined Smith's body signed the cause of death as undetermined-though there was strong evidence to suggest otherwise-Chiba has been viciously attacked by fans who claim she murdered their hero, though in reality she was never formally charged with the crime. Schultz proposes that Smith's death was not the result of Chiba's hand, but rather an accumulating series of events-depression, addiction, and paranoia-that led to suicide. "Death was the final unburdening, a formula Elliott always espoused" (327). This is Schultz's final deconstruction of "The Smith Myth."

Torment Saint is an important book precisely because it represents the first comprehensive academic engagement with Elliott Smith. Other monographs and hybrid photo books, most notably Elliott Smith (2007) by Autumn de Wilde and Elliott Smith and the Big Nothing (2005) by Benjamin Nugent, have satisfied fandom but do little in providing a rigorous analysis of Smith's biography and its relationship to his musical production. For this reason, the book complements the growing literature on the history of alternative music, 
popular culture, and a convincing argument for the role of psychology and life history dynamics within the field of musicology. Torment Saint is a remarkable contribution to the limited research on Smith and stands as the definitive book on the musician. It is strongly recommended for musicology scholars with special interest in lyricism, music composition, and artist biography, but its language and themes are accessible to interest a wide audience.

\section{WORKS Cited}

De Wilde, Autumn. 2007. Elliott Smith. San Francisco: Chronicle Books. Nugent, Benjamin. 2005. Elliott Smith and the Ballad of Big Nothing. Cambridge, MA: De Capo.

Matthew Ryan Smith

Michael Goddard, Benjamin Halligan, and Nicola Spelman. Resonances: Noise and Contemporary Music. New York: Bloomsbury Academic, 2013. 375 pp. ISBN 978-1-4411-5937-3.

Resonances grew out of the University of Salford's 2010 conference, "Bigger than Words, Wider than Pictures: Noise, Affect, Politics." Along with its sibling collection, Reverberations (2012), Resonances joins the proliferation of monographs and collections published recently that look at the subject of noise in various cultural fields. ${ }^{1}$ As part of an exciting line of publications on music from Bloomsbury, this collection is populated by essays from a mix of scholars and artists who offer a range of perspectives on noise in current musics and, to a lesser extent, on the ways in which current musics relate to the potential expansion of noise as a concept. To do justice to each of the nineteen essays would require much more space than is afforded here; I will approach the collection by thinking about some productive points of tension that emerge-what might be called the collection's noise. This emphasis on noise is in no way a dismissal of what is, overall, a compelling and valuable collection that brings marginalized musics to the fore.

The dynamics of noise and the ways it can operate allow for infinitely different lines of inquiry, because what its definitions attempt to fix constantly evade such static meanings-this slippage is itself a type of noise. Put simply, the term does what it says. Taking the work of Jacques Attali's seminal Noise: The Political Economy of Music (1985), Douglas Kahn's Noise, Water, Meat: A History of Sound in the Arts (1999), and Paul Hegarty's Noise/Music: A History (2007) as forebears, the editors open the collection by working through some possible definitions of noise, such as how contemporary histories of Western music are concerned with its role in marking music versus non-music, or the

1 A sample of other titles on noise: Haigne (2013), Krapp (2011), Nunes (2012), and Schwartz (2011). Another prominent example is the conference "Noise in and as Music," 4-6 October 2013 at the University of Huddersfield, organized by Aaron Einbond and Aaron Cassidy, accompanied by the publication of a collection by the same name. 